\title{
Use of gene probes and adhesion tests to characterise Escherichia coli belonging to enteropathogenic serogroups isolated in the United Kingdom
}

\author{
S. M. SCOTLAND, H. R. SMITH*, T. CHEASTY, B. SAID, G. A. WILLSHAW, N. STOKES and B. \\ ROWE
}

Laboratory of Enteric Pathogens, Central Public Health Laboratory, 61 Colindale Avenue, London NW9 5HT

\begin{abstract}
Nine hundred and twenty-five Escherichia coli isolates from cases of diarrhoea in the United Kingdom and belonging to enteropathogenic $E$. coli (EPEC) $O$ serogroups were examined for virulence properties. The tests included adhesion to HEp-2 cells, the fluorescence actin staining (FAS) test (which correlates with the ability to cause attaching and effacing lesions) and DNA hybridisations with probes to detect sequences for eaeA ( $E$. coli attaching and effacing factor), EAF (EPEC adherence factor), verocytotoxins VT1 and VT2, enteroaggregative $E$. coli and diffusely adherent $E$. coli. The $O$ serogroups examined were 18, 26, 44, 55, 86, 111, 114, 119, 125, 126, 127, 128 and 142. Six hundred and sixty strains $(\mathbf{7 1 . 4 \% )}$ hybridised with at least one of the DNA probes. Over $80 \%$ of strains in $O$ serogroups $26,55,119,125,127$ and 142 and $41 \%$ of strains of serogroups 86, 111, 114, 126 and 128 hybridised with the eae probe and most showed localised attachment and were FAS-positive. However, $<10 \%$ of these $e a e$ probepositive strains hybridised with the EAF probe. Eighty-four of 232 strains in 0 serogroups $44,86,111$, and 126 were enteroaggregative. VT genes were detected in 57 of 402 strains in $O$ serogroups $26,55,111$ and 128 . Identification of EPEC by serogrouping was shown to be an effective method of identifying strains with pathogenic potential, although the organisms were diverse in their properties.
\end{abstract}

\section{Introduction}

Enteropathogenic strains of Escherichia coli (EPEC) were first recognised to cause infantile enteritis in the 1940s. They were shown to belong to a restricted range of $\mathrm{O}$ serogroups and commercial antisera became available for their identification $[1,2]$. Later it was shown that some strains of $E$. coli caused diarrhoea because they produced enterotoxins, or produced a verocytotoxin (VT), or were able to invade epithelial cells [3]. These groups of pathogenic $E$. coli were termed enterotoxigenic $E$. coli (ETEC), verocytotoxin producing $E$. coli (VTEC) or enteroinvasive $E$. coli (EIEC), respectively. However, characteristic EPEC strains isolated from outbreaks of diarrhoea did not belong to any of these groups, although occasionally strains belonging to EPEC serogroups and isolated from sporadic cases of diarrhoea did produce enterotoxins or VT [4].

A property possessed by typical EPEC strains was the

Received 19 Oct. 1995; accepted 28 Oct. 1995.

${ }^{*}$ Correspondence should be sent to $\mathrm{Dr}$ H. R. Smith. ability to adhere in characteristic localised clusters to HEp-2 cells grown in tissue culture [5]. This adherence was shown subsequently to be accompanied by structural changes in the cells which resulted in the accumulation of polymerised actin beneath the attached bacteria, visualised by the use of fluorescein isothiocyanate-labelled phalloidin in the fluorescence actin staining (FAS) test [6]. These in-vitro tests with HEp-2 cells were shown to correlate with the ability of typical EPEC to cause attaching and effacing (AE) lesions of intestinal epithelial biopsy material. The ability of such EPEC strains to adhere well in vitro was shown to depend on the possession of a plasmid. An $E$. coli adherence factor (EAF) probe was developed from gene sequences carried on a plasmid in strain E2348/69 (serotype O127:H6) [7]. Subsequently, chromosomal gene sequences were shown to be necessary for the formation of $\mathrm{AE}$ lesions as judged by the FAS test and the eae (E. coli attaching and $e$ ffacing) probe was developed from the same $E$. coli strain [8]. In addition to the localised attachment (LA) shown by typical EPEC, other patterns of adhesion to HEp-2 cells have been recognised. These are the aggregative and diffuse patterns; strains 
exhibiting these types of attachment have been termed enteroaggregative $E$. coli (EAggEC) and diffusely adherent E. coli (DAEC) [4].

Strains in EPEC O serogroups 18, 26, 44, 55, 86, 111, $114,119,125,126,127,128$ and 142 that were isolated from cases of diarrhoea and received by the Laboratory of Enteric Pathogens in the years 19851993 were examined. They were tested for adhesion to HEp-2 cells and for hybridisation with several probes used to identify the different classes of diarrhoeagenic E. coli.

\section{Materials and methods}

\section{Bacterial strains}

The strains were received from laboratories in many different areas of the United Kingdom. They were isolated from the faeces of patients of all ages with diarrhoea during the period 1985-1993; $867(94 \%)$ of the 925 strains were from children $<4$ years old. The strains were identified and serotyped with antisera to $O$ antigens $1-173$ and $H$ antigens 1-55 [9]. Some of the strains have been included in previous studies [10-12].

\section{DNA hybridisation}

Strains were tested by colony hybridisation [13]. The VT1 probe was a $0.75-\mathrm{kb}$ Hinc II fragment derived from strain H19 (E. coli 026:H11) and the VT2 probe was a $0.85-\mathrm{kb} A v a \mathrm{I}-P s t \mathrm{I}$ fragment derived from strain E32511 (E. coli 0157:H-) [14]. The VT probes were labelled with fluorescein-dUTP or digoxigenin and used as described previously $[15,16]$. The eae and EAF probes were derived from strain E2348/69 [7, 8]. The EAggEC probe was that described by Baudry $e t$ al. [17] and the DAEC probe was a 370-bp Pst I fragment within the daa $\mathrm{C}$ gene of strain $\mathrm{C} 1845$ [18]. The eae, EAF, EAggEC and DAEC probes were labelled with fluorescein-dUTP. Hybridisation and washing were under stringent conditions with the following exceptions. For the EAggEC probe, membranes were washed twice at room temperature for $15 \mathrm{~min}$ in $2 \times \mathrm{SSC}$, SDS $0.1 \%$ and then in $5 \times \mathrm{SSC}$, SDS $0.1 \%$ for $15 \mathrm{~min}$ at $54^{\circ} \mathrm{C}$ followed by $30 \mathrm{~s}$ at room temperature in $2 \times$ SSC, SDS $0.1 \%$. Membranes from DAEC probe tests were washed twice at room temperature for $15 \mathrm{~min}$ in $2 \times \mathrm{SSC}$, SDS $0.1 \%$ and then in $0.5 \times \mathrm{SSC}$, SDS $0.1 \%$ at $68^{\circ} \mathrm{C}$ for $15 \mathrm{~min}$.

\section{Adhesion tests}

Adhesion to HEp-2 cells was tested in the presence of D-mannose $1 \% \mathrm{w} / \mathrm{v}$ as described previously [19]. The pattern of adhesion was assessed as localised, diffuse or aggregative at the end of a 6-h test. All the strains that showed no adhesion were tested in at least two experiments. The FAS test was that of Knutton et al. [6].

\section{Results}

\section{Testing of strains with DNA probes}

Of the $925 E$. coli strains isolated in the UK and belonging to $13 \mathrm{O}$ serogroups tested for hybridisation with the eae, EAF, EAggEC, DAEC and VT probes, $660(71.4 \%)$ strains hybridised with at least one probe (Table 1).

The largest number of strains (520) hybridised with the eae probe. Within each serogroup the positive strains were usually of particular $\mathrm{O}: \mathrm{H}$ combinations and there were also some non-motile strains. The eaepositive serotypes most commonly found were O26:H11, O26:H-, O55:H7, O55: $\mathrm{H} 34, \quad \mathrm{O} 55: \mathrm{H}-$, O111:H25, O119:H2, O125:H6, O127:H40, O127:H45, O127:H-, O128:H2 and O128:H8. These 13 serotypes accounted for $80 \%$ of the eae-positive strains although there was a total of 51 eae-positive serotypes identified. The eae genes were found in all serogroups except 018 and O44. Results of the EAF probe tests showed that 49 strains were positive and all except one 018:H4 strain also hybridised with the eae probe.

One hundred and twenty-one strains were EAggECprobe positive. All these strains gave negative results with the eae probe and the majority belonged to distinct $\mathrm{O}: \mathrm{H}$ serotypes such as $\mathrm{O} 44: \mathrm{H} 18, \mathrm{O} 111: \mathrm{H} 21$, O126:H27 and O128:H35. Some of the EAggEC probe-positive strains also hybridised with the DAEC probe as observed in a recent study of O44:H18 strains [20]. In addition to these strains that hybridised with both the EAggEC and DAEC probes, there were 10 strains that hybridised with the DAEC probe and not the EAggEC probe (Table 1). Four of these 10 DAEC probe-positive strains, all of which were of serotype $\mathrm{O} 55: \mathrm{H}-$, were unusual in that they hybridised with the eae probe.

VT genes were detected in 57 strains of serogroups O26, 055, 0111 and 0128; 41 of these VTEC strains were in serogroup 026 and most were $\mathrm{O} 26: \mathrm{H} 11$, as found in previous studies [12,21]. Forty-five of the 57 VTEC strains also hybridised with the eae probe and the remaining 12 eae-negative strains were in serogroup 0128 .

Two hundred and sixty-five strains did not hybridise with any of the probes and 90 of these belonged to serogroup $\mathrm{O} 18$ (Table 2). The remaining probe-negative strains belonged to all 12 serogroups but there were no more than eleven strains of any individual $\mathrm{O}: \mathrm{H}$ serotype.

\section{Adhesion to cell cultures}

Selected strains were examined for attachment to HEp2 cells and the results were correlated with those of the hybridisation tests (Tables 3 and 4). All 47 strains 
Table 1. Properties of strains that hybridise with DNA probes

\begin{tabular}{|c|c|c|c|c|c|c|c|c|}
\hline \multirow[b]{2}{*}{ Serogroup } & \multirow{2}{*}{$\begin{array}{l}\text { Number positive/ } \\
\text { total tested }\end{array}$} & \multirow{2}{*}{$\begin{array}{l}\text { Number of } \\
\text { strains }\end{array}$} & \multicolumn{5}{|c|}{ Hybridisation with } & \multirow[b]{2}{*}{$\mathrm{H}$ type (number) } \\
\hline & & & $e a e$ & EAF & EAggEC & DAEC & VT & \\
\hline 018 & $1 / 91$ & 1 & & + & & & & $4(1)$ \\
\hline \multirow[t]{3}{*}{026} & $123 / 128$ & 81 & + & & & & & $8(2), 11(18),-(61)$ \\
\hline & & 41 & + & & & & + & $11(35), 21(1), 32(1),-(4)$ \\
\hline & & 1 & + & + & & & & 2(1) \\
\hline \multirow[t]{2}{*}{044} & $14 / 21$ & 2 & & & + & & & $18(1), 41(1)$ \\
\hline & & 12 & & & + & + & & $7(1), 18(11)$ \\
\hline \multirow[t]{6}{*}{055} & $96 / 116$ & 80 & + & & & & & $7(35), 34(22), 35(2), 42(1),-(20)$ \\
\hline & & 4 & + & + & & & & $-(4)$ \\
\hline & & 4 & + & & & + & & $-(4)$ \\
\hline & & 2 & + & & & & + & $7(2)$ \\
\hline & & 5 & & & + & & & $4(1), 10(2), 12(1),-(1)$ \\
\hline & & 1 & & & + & + & & $27(1)$ \\
\hline \multirow[t]{4}{*}{086} & $25 / 40$ & 11 & + & & & & & $8(9), 45(1),-(1)$ \\
\hline & & 3 & + & + & & & & $34(1),-(2)$ \\
\hline & & 10 & & & + & & & $2(2), 6(2), 11(1), 18(3), 21(1),-(1)$ \\
\hline & & 1 & & & & + & & $18(1)$ \\
\hline \multirow{4}{*}{0111} & 79/92 & 31 & + & & & & & $25(31)$ \\
\hline & & 5 & + & + & & & & $-(5)$ \\
\hline & & 1 & + & & & & & $-(1)$ \\
\hline & & 42 & & & + & & & $7(2), 12(2), 21(21),-(16), ?(1)$ \\
\hline \multirow[t]{4}{*}{0114} & $17 / 33$ & 9 & + & & & & & $19(1), 49(8)$ \\
\hline & & 6 & + & + & & & & $2(5),-(1)$ \\
\hline & & 1 & & & + & & + & $-(1)$ \\
\hline & & 1 & & & + & + & & $9(1)$ \\
\hline \multirow{2}{*}{0119} & $29 / 31$ & 24 & + & & & & & $2(22), 6(1),-(1)$ \\
\hline & & 5 & + & + & & & & $6(4),-(1)$ \\
\hline \multirow[t]{3}{*}{0125} & $48 / 61$ & 41 & + & & & & & $6(38),-(3)$ \\
\hline & & 5 & + & + & & & & $21(1),-(4)$ \\
\hline & & 2 & & & + & & & $9(2)$ \\
\hline \multirow[t]{4}{*}{0126} & $49 / 79$ & 4 & + & & & & & $6(4)$ \\
\hline & & 9 & + & + & & & & $2(2),-(7)$ \\
\hline & & 32 & & & + & + & & $27(31),-(1)$ \\
\hline & & 4 & & & & + & & $27(2), 33(1), 43(1)$ \\
\hline \multirow[t]{3}{*}{0127} & $55 / 69$ & 50 & + & & & & & $4(1), 40(13), 45(12),-(24)$ \\
\hline & & 4 & + & + & & & & $6(1),-(3)$ \\
\hline & & 1 & & & + & & & $21(1)$ \\
\hline \multirow[t]{6}{*}{0128} & $104 / 140$ & 76 & + & & & & & $\begin{array}{l}2(54), 8(12), 11(1), 12(1), 47(1) \\
-(7)\end{array}$ \\
\hline & & 2 & + & + & & & & $2(1),-(1)$ \\
\hline & & 1 & + & & & & + & $25(1)$ \\
\hline & & 12 & & & & & + & $2(11),-(1)$ \\
\hline & & 12 & & & + & & & $7(1), 35(11)$ \\
\hline & & 1 & & & & + & & $10(1)$ \\
\hline \multirow[t]{2}{*}{0142} & $20 / 24$ & 16 & + & & & & & $6(2), 10(1), 23(1), 34(6), 35(2)$ \\
\hline & & 4 & + & + & & & & $\begin{array}{l}30(2), 52(1),-(1) \\
4(1), 6(3)\end{array}$ \\
\hline
\end{tabular}

examined that were eae- and EAF-probe-positive showed localised adhesion, although there was considerable variation in the percentage of HEp-2 cells with adherent bacteria. Of the 321 strains that hybridised with the eae probe but were EAF-negative, 201 showed some LA. The percentage of cells that showed LA ranged from 1 to 92 and was usually lower than adhesion observed with the eae-positive, EAF-

Table 2. Flagellar $(\mathrm{H})$ types of strains that did not hybridise with probes

\begin{tabular}{lrlr}
\hline Serogroup & Total & \multicolumn{1}{c}{ H types (number) } & $\begin{array}{c}\text { Number of non- } \\
\text { motile strains }\end{array}$ \\
\hline O18 & 90 & $1(6), 4(2), 5(3), 7(41), 8(1), 14(2), 49(1)$, & 34 \\
O26 & 5 & $32(4)$ & 1 \\
O44 & 7 & $5(1), 18(5), 41(1)$ & 0 \\
O55 & 20 & $1(1), 9(2), 12(5), 22(1), 24(1), 27(5), 32(4), 45(1)$ & 0 \\
O86 & 15 & $4(1), 8(1), 10(1), 18(1), 20(1), 27(2), 30(2), 43(1)$ & 5 \\
O111 & 13 & $12(3), 19(1), 45(4)$ & 5 \\
O114 & 16 & $4(6), 9(4), 10(1), 25(2)$ & 3 \\
O119 & 2 & $4(1)$ & 1 \\
O125 & 13 & $19(2), 21(1), 30(9)$ & 1 \\
O126 & 30 & $2(4), 6(1), 7(1), 8(1), 20(1), 21(5), 27(11), 45(1), 49(1), 51(1)$ & 3 \\
O127 & 14 & $4(2), 5(1), 21(2), 40(6)$ & 3 \\
0128 & 36 & $1(9), 2(1), 9(1), 12(5), 19(1), 27(1), 35(6), 45(1), 46(1), 47(1), 49(1)$ & 8 \\
0142 & 4 & $4(1), 11(1), 38(2)$ & 0 \\
\hline
\end{tabular}


Table 3. Examination of eae-positive strains and correlation with EAF probe and cell tests

\begin{tabular}{|c|c|c|c|c|c|c|}
\hline \multirow[b]{2}{*}{ Serogroup } & \multirow[b]{2}{*}{ H type (n) } & \multirow[b]{2}{*}{ Total } & \multirow{2}{*}{$\begin{array}{l}\text { EAF } \\
\text { probe }\end{array}$} & \multicolumn{2}{|c|}{ Percentage of cells with LA $^{*}$} & \multirow{2}{*}{$\begin{array}{l}\text { Number of strains } \\
\text { with no attachment }\end{array}$} \\
\hline & & & & Range & Mean & \\
\hline \multirow[t]{3}{*}{026} & - & 24 & - & $1-32$ & 9.5 & 3 \\
\hline & 11 & $18(13 \mathrm{VT}+)$ & - & $1-52$ & 13.6 & 0 \\
\hline & 32 & 1 & - & & & 1 \\
\hline \multirow[t]{6}{*}{055} & - & 4 & + & $96-100$ & 99 & 0 \\
\hline & - & $4^{\dagger}$ & - & & & Diffuse adhesion \\
\hline & 7 & 31 & - & $1-56$ & 20.2 & 7 \\
\hline & - & 14 & - & $1-68$ & 12.8 & 6 \\
\hline & 34 & 18 & - & $1-52$ & 10.0 & 7 \\
\hline & $42(1) 35(1)$ & 2 & - & & & 2 \\
\hline \multirow[t]{3}{*}{086} & $34(1)-(2)$ & 3 & + & $32-56$ & 45 & 0 \\
\hline & 8 & 10 & - & $1-50$ & 25 & 8 \\
\hline & 45 & 1 & - & 21 & & 0 \\
\hline \multirow{3}{*}{0111} & - & 5 & + & $46-100$ & 79 & 0 \\
\hline & 25 & 30 & - & $1-24$ & 4.9 & 15 \\
\hline & - & $1 \mathrm{VT}+$ & - & 4 & & 0 \\
\hline \multirow[t]{3}{*}{0114} & $2(5),-(1)$ & 6 & + & $20-100$ & 54 & 0 \\
\hline & 49 & 8 & - & $1-18$ & 5.3 & 4 \\
\hline & 19 & 1 & - & 17 & & 0 \\
\hline \multirow[t]{4}{*}{0119} & $6(4)-(1)$ & 5 & + & $13-70$ & 34 & 0 \\
\hline & 2 & 21 & - & $1-21$ & 6.5 & 10 \\
\hline & - & 1 & - & & & 0 \\
\hline & 6 & 1 & - & 72 & & 0 \\
\hline \multirow[t]{3}{*}{0125} & $21(1)-(4)$ & 5 & + & $6-52$ & 29 & 0 \\
\hline & 6 & 19 & - & $2-24$ & 6.4 & 6 \\
\hline & - & 3 & - & $1-29$ & 15 & 1 \\
\hline \multirow{2}{*}{0126} & $2(2)-(7)$ & 9 & + & $4-58$ & 25 & 0 \\
\hline & & 4 & - & $3-11$ & 6 & 1 \\
\hline \multirow[t]{4}{*}{0127} & $6(1)-(3)$ & 4 & + & $40-100$ & 77 & 0 \\
\hline & - & 22 & - & $2-7$ & 4.5 & 20 \\
\hline & 45 & 12 & - & $1-5$ & 2.5 & 4 \\
\hline & 40 & 13 & - & & & 13 \\
\hline \multirow[t]{5}{*}{0128} & $2(1)-(1)$ & 2 & + & $74-100$ & 87 & 0 \\
\hline & 2 & 34 & - & $1-92$ & 24.6 & 1 \\
\hline & _- & 4 & - & $5-50$ & 27.5 & 2 \\
\hline & 8 & 7 & - & $2-42$ & 13 & 0 \\
\hline & 11 & 1 & - & 22 & & 0 \\
\hline \multirow{5}{*}{0142} & $4(1) 6(3)$ & 4 & + & $20-100$ & 62 & 0 \\
\hline & $6(2) 10(1)$ & 16 & - & $1-22$ & 5.8 & 5 \\
\hline & $23(1) 34(6)$ & & & & & \\
\hline & $35(2) \quad 36(2)$ & & & & & \\
\hline & $52(1)-(1)$ & & & & & \\
\hline
\end{tabular}

*A selection of LA strains of all serotypes was FAS positive. The eae DA O55 strains were FAS negative.

${ }^{\dagger}$ These four strains hybridised with the eae and DAEC probes.

positive strains. Certain $\mathrm{O}: \mathrm{H}$ combinations such as O111:H25, O119:H2, O127:H- and O127:H40 showed a high proportion of eae probe-positive, LA-negative strains; in particular, 37 of 47 serogroup 0127 strains gave this result (Table 3).

A selection from all serogroups of the strains that showed LA was examined in the FAS test; all these strains gave positive results. However, four $\mathrm{O} 55: \mathrm{H}-$ strains that hybridised with the eae and DAEC probes only showed diffuse adhesion and were FAS-negative.

The results of the EAggEC and DAEC probe tests were also correlated with adhesion assays (Table 4). A total of 122 probe-positive strains was examined and 99 showed either the aggregative or diffuse adhesion pattern. The 23 strains that showed no adhesion to HEp-2 cells included all 11 strains of serotype O128:H35 that hybridised with the EAggEC probe.

\section{Discussion}

Over $70 \%$ of the strains from the 13 EPEC serogroups hybridised with at least one of the DNA probes for virulence factors or putative virulence factors. The eae property was found in $>80 \%$ of strains belonging to $\mathrm{O}$ serogroups $26,55,119,125,127$ and 142 and in $>40 \%$ of strains of $O$ serogroups $86,111,114,126$ and 128 . The majority of these eae probe-positive strains gave LA and were FAS test positive. However, $>90 \%$ of these eae probe-positive strains were unlike typical EPEC in that they did not hybridise with the EAF probe. Some of the EAF-positive strains belonged to serotypes usually associated with outbreaks of infantile gastroenteritis such as $\mathrm{O} 55: \mathrm{H}-, \mathrm{O} 114: \mathrm{H} 2, \mathrm{O} 119: \mathrm{H} 6$, O126:H2, O127:H6, O128:H2 and O142:H6. The majority of the EAF-negative strains belonged to serotypes that were different from those of the EAF-positive strains. Therefore, it is unlikely that the 
Table 4. Correlation of EAggEC and DAEC probes with cell tests

\begin{tabular}{|c|c|c|c|c|c|}
\hline \multirow[b]{2}{*}{ Serogroup } & \multirow[b]{2}{*}{ H type (n) } & \multirow{2}{*}{$\begin{array}{l}\text { Number of } \\
\text { strains }\end{array}$} & \multicolumn{2}{|c|}{ Probe result } & \multirow{2}{*}{$\begin{array}{l}\text { Adhesion } \\
\text { type }\end{array}$} \\
\hline & & & EAggEC & DAEC & \\
\hline \multirow[t]{2}{*}{044} & $7(1) 18(11)$ & 12 & + & + & Agg \\
\hline & $18(1) 41(1)$ & 2 & + & & Agg \\
\hline \multirow[t]{3}{*}{ O55 } & 27 & 1 & + & + & Agg \\
\hline & 12 & 1 & + & & Agg \\
\hline & $4(1), 10(2),-(1)$ & 4 & + & & None \\
\hline \multirow[t]{4}{*}{086} & $2(2) 6(2) 11(1) 18(2)$ & 9 & + & & Agg \\
\hline & $21(1)-(1)$ & & & & \\
\hline & 18 & 1 & + & & None \\
\hline & 18 & 1 & & + & $\mathrm{DA}$ \\
\hline \multirow[t]{2}{*}{0111} & $\begin{array}{l}7(2) 12(1) 21(21) \\
-(15) ?(1)\end{array}$ & 40 & + & & Agg \\
\hline & $12(1),-(1)$ & 2 & + & & None \\
\hline \multirow[t]{2}{*}{0114} & - & 1 & + & & Agg \\
\hline & 9 & 1 & + & + & None \\
\hline \multirow{2}{*}{0125} & 9 & $i$ & + & & Agg \\
\hline & 9 & 1 & + & & None \\
\hline \multirow[t]{5}{*}{0126} & $27(25)-(1)$ & 26 & + & + & Agg \\
\hline & 27 & 2 & + & + & None \\
\hline & 27 & 1 & & + & Agg \\
\hline & 27 & 1 & & + & None \\
\hline & $33(1), 45(1)$ & 2 & & + & DA \\
\hline 0127 & 21 & 1 & + & & Agg \\
\hline \multirow[t]{2}{*}{0128} & 35 & 11 & + & & None \\
\hline & 10 & 1 & & + & DA \\
\hline
\end{tabular}

EAF-negative strains resulted from loss of the EAF plasmid from positive strains.

Although most eae probe-positive strains showed LA, the lack of attachment in some cases may suggest that there is no or very poor expression of the eaeA gene or other genes. Recent studies have shown that the EAF plasmid controls the expression of the eaeA gene product, a $94-\mathrm{kDa}$ protein termed intimin [22]. The perA locus, a plasmid encoded regulator, increases expression of intimin by 100 -fold and this perA gene has been detected in all EPEC strains that carry the EAF plasmid. In this study, all the eae-positive, EAFpositive strains expressed LA and were FAS testpositive. The presence of the perA locus or a similar regulatory gene in the eae-positive, EAF-negative strains is not yet known. The EAF plasmid also carries the $b f p \mathrm{~A}$ gene that encodes bundle-forming pili (BFP) and it has been suggested that these pili are an adhesin of EPEC [23]. The $b f p \mathrm{~A}$ and EAF probes were correlated in a recent study [24] and this demonstrated that the $b f p A$ probe hybridised with 137 of 138 EAF-positive strains and only with 10 EAF-negative strains. Hybridisation of the eae-positive, EAF-negative strains examined in the present study with a $b f p A$ probe would provide further information on the distribution of these pili in EPEC.

Many strains belonging to $\mathrm{O}$ serogroups 44, 86, 111 and 126 were enteroaggregative by probe and adhesion tests and in a total of nine serogroups there were EAggEC probe-positive strains. This extends the range of EPEC O serogroups that contain EAggEC [4, 11, $20,25]$ and supports the suggestion that EAggEC may be a significant cause of diarrhoea in Britain. Previous studies demonstrated that the aggregative pattern of adherence is usually plasmid determined [25] and in strain 17-2, serotype $\mathrm{O} 3: \mathrm{H} 2$, plasmid-encoded genes specified bundle-forming fimbriae on the surface [26]. At present it is not clear whether EAggEC strains of different serotypes specify antigenically distinct adhesins. Tests suitable for clinical diagnostic laboratories need to be developed so that the importance of EAggEC can be assessed.

There has been some controversy over the virulence of EPEC and many laboratories have discontinued testing for EPEC [4, 27]. The results of this study have demonstrated that identification of EPEC by serogrouping is an effective method of identifying strains of $E$. coli with pathogenic potential, although the organisms were diverse in their properties. In particular, the virulence of eae-positive, EAF-negative strains and of EAggEC strains needs further evaluation.

\section{References}

1. Taylor J. Host specificity and enteropathogenicity of Escherichia coli. J Appl Bacteriol 1961; 24: 316-325.

2. Gross RJ. Escherichia coli diarrhoea. In: Smith GR, Easmon CSF (eds) Topley and Wilson's Principles of bacteriology, virology and immunity, 8th edn, Vol 3. London, Edward Arnold. 1990: 469-487.

3. Levine MM. Escherichia coli that cause diarrhea: enterotoxigenic, enteropathogenic, enteroinvasive, enterohemorrhagic, and enteroadherent. $J$ Infect Dis 1987; 155: 377-389.

4. Law D. Adhesion and its role in the virulence of enteropathogenic Escherichia coli. Clin Microbiol Rev 1994; 7: 152-173.

5. Cravioto A, Gross RJ, Scotland SM, Rowe B. An adhesive factor found in strains of Escherichia coli belonging to the traditional infantile enteropathogenic serotypes. Curr Microbiol 1979; 3: 95-99.

6. Knutton S, Baldwin T, Williams PH, McNeish AS. Actin 
accumulation at sites of bacterial adhesion to tissue culture cells: basis of a new diagnostic test for enteropathogenic and enterohemorrhagic Escherichia coli. Infect Immun 1989; 57: 1290-1298.

7. Baldini MM, Nataro JP, Kaper JB. Localization of a determinant for HEp-2 adherence by enteropathogenic Escherichia coli. Infect Immun 1986; 52: 334-336.

8. Jerse $\mathrm{AE}$, Yu J, Tall BD, Kaper JB. A genetic locus of enteropathogenic Escherichia coli necessary for the production of attaching and effacing lesions on tissue culture cells. Proc Natl Acad Sci USA 1990; 87: 7839-7843.

9. Gross RJ, Rowe B. Serotyping of Escherichia coli. In: Sussman M (ed) The virulence of Escherichia coli. Reviews and methods. London, Academic Press. 1985: 345-363.

10. Smith HR, Scotland SM, Stokes N, Rowe B. Examination of strains belonging to enteropathogenic Escherichia coli serogroups for genes encoding EPEC adherence factor and verocytotoxins. J Med Microbiol 1990; 31: 235-240.

11. Scotland SM, Smith HR, Said B, Willshaw GA, Cheasty T, Rowe B. Identification of enteropathogenic Escherichia coli isolated in Britain as enteroaggregative or as members of a subclass of attaching-and-effacing $E$. coli not hybridising with the EPEC adherence-factor probe. $J$ Med Microbiol 1991; 35: 278-283.

12. Scotland SM, Willshaw GA, Smith HR, Said B, Stokes N, Rowe B. Virulence properties of Escherichia coli strains belonging to serogroups $\mathrm{O} 26, \mathrm{O} 55, \mathrm{O} 111$ and 0128 isolated in the United Kingdom in 1991 from patients with diarrhoea. Epidemiol Infect 1993; 111: 429-438.

13. Willshaw GA, Smith HR, Scotland SM, Rowe B. Cloning of genes determining the production of Vero cytotoxin by Escherichia coli. J Gen Microbiol 1985; 131: 3047-3053.

14. Willshaw GA, Smith HR, Scotland SM, Field AM, Rowe B. Heterogeneity of Escherichia coli phages encoding Vero cytotoxins: comparison of cloned sequences determining VT1 and VT2 and development of specific gene probes. J Gen Microbiol 1987; 133: 1309-1317.

15. Thomas A, Smith HR, Willshaw GA, Rowe B. Non-radioactively labelled polynucleotide and oligonucleotide DNA probes, for selectively detecting Escherichia coli strains producing Vero cytotoxins VT1, VT2 and VT2 variant. Mol Cell Probes 1991; 5: 129-135.

16. Willshaw GA, Thirlwell J, Jones AP, Parry S, Salmon RL, Hickey M. Vero cytotoxin-producing Escherichia coli 0157 in beefburgers linked to an outbreak of diarrhoea, haemorrhagic colitis and haemolytic uraemic syndrome in Britain. Lett Appl Microbiol 1994; 19: 304-307.

17. Baudry B, Savarino SJ, Vial P, Kaper JB, Levine MM. A sensitive and specific DNA probe to identify enteroaggregative Escherichia coli, a recently discovered diarrheal pathogen. $J$ Infect Dis 1990; 161: 1249-1251.

18. Bilge SS, Clausen CR, Lau W, Moseley SL. Molecular characterization of a fimbrial adhesin, F1845, mediating diffuse adherence of diarrhea-associated Escherichia coli to HEp-2 cells. $J$ Bacteriol 1989; 171: 4281-4289.

19. Scotland SM, Willshaw GA, Smith HR, Gross RJ, Rowe B. Adhesion to cells in culture and plasmid profiles of enteropathogenic Escherichia coli isolated from outbreaks and sporadic cases of infant diarrhoea. $J$ Infect 1989; 19: 237-249.

20. Smith HR, Scotland SM, Willshaw GA, Rowe B, Cravioto A, Eslava C. Isolates of Escherichia coli $\mathrm{O} 44: \mathrm{H} 18$ of diverse origin are enteroaggregative. J Infect Dis 1994; 170: 1610 1613.

21. Scotland SM, Willshaw GA, Smith HR, Rowe B. Properties of strains of Escherichia coli $\mathrm{O} 26: \mathrm{H} 11$ in relation to their enteropathogenic or enterohemorrhagic classification. $J$ Infect Dis 1990; 162: 1069-1074.

22. Donnenberg MS, Kaper JB. Enteropathogenic Escherichia coli. Infect Immun 1992; 60: 3953-3961.

23. Girón JA, Ho ASY, Schoolnik GK. An inducible bundleforming pilus of enteropathogenic Escherichia coli. Science 1991; 254: 710-713.

24. Girón JA, Donnenberg MS, Martin WC, Jarvis KG, Kaper JB. Distribution of the bundle-forming pilus structural gene $(b f p \mathrm{~A})$ among enteropathogenic Escherichia coli. J Infect Dis 1993; 168: $1037-1041$.

25. Vial PA, Robins-Browne $\mathrm{R}$, Lior $\mathrm{H}$ et al. Characterization of enteroadherent-aggregative Escherichia coli, a putative agent of diarrheal disease. $J$ Infect Dis 1988; 158: 70-79.

26. Nataro JP, Deng Y, Maneval DR, German AL, Martin WC, Levine MM. Aggregative adherence fimbriae I of enteroaggregative Escherichia coli mediate adherence to HEp-2 cells and hemagglutination of human erythrocytes. Infect Immun 1992; 60: 2297-2304.

27. Morris KJ, Rao GG. Conventional screening for enteropathogenic Escherichia coli in the UK. Is it appropriate or necessary? J Hosp Infect 1992; 21: 163-167. 